\title{
Identification of Human Papillomavirus DNA in Cutaneous Lesions of Cowden Syndrome
}

\author{
Jörg Schaller ${ }^{a}$ Angela Rohwedder ${ }^{b}$ Walter H.C. Burgdorf ${ }^{c}$ Peter H. Itin ${ }^{d}$ \\ Stephan Lautenschlager ${ }^{\mathrm{e}}$ \\ a Department of Dermatology, Dermatohistological Unit, St. Barbara Hospital, Duisburg, bepartment of Virology, \\ Ruhr University, Bochum, and 'Department of Dermatology, Ludwig Maximilian University, Munich, Germany; \\ dUniversity Hospital, Basel, Kantonsspital, Aarau, and e Outpatient Clinic of Dermatology, Triemli Hospital, \\ Zürich, Switzerland
}

\section{Key Words \\ Cowden syndrome - Trichilemmoma • Warty lesions · Epidermodysplasia-associated HPV types}

\begin{abstract}
Background: Cowden syndrome (CS) or multiple hamartoma syndrome is a cancer-associated genodermatosis inherited in an autosomal dominant pattern. One of the diagnostic criteria is facial papules which are felt to be trichilemmomas, benign hair follicle tumors, which some consider to be induced by human papillomavirus (HPV). Objective: To search for HPV in skin tumors, especially trichilemmomas, from patients with CS. Methods: Skin lesions from patients with CS were classified histologically. Each tumor was then analyzed for HPV DNA by polymerase chain reaction with different primer sets; positive amplicons were typed by direct sequencing. Results: Twenty-nine biopsies from 7 patients with CS were investigated. Only 2 of 29 tumors clinically suspected of being trichilemmomas were confirmed histologically. In addition, 3 sclerotic fibromas, also typical of CS, were found, as well as 1 sebaceous hyperplasia. The other 23 lesions showed histological features of HPV-
\end{abstract}

\section{KARGER}

Fax +41613061234

E-Mail karger@karger.ch

www.karger.com

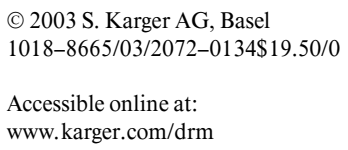

induced tumors in various stages of development. HPV DNA was found in 19 of 29 cutaneous lesions. Tumors without any histological signs of HPV induction were negative for HPV DNA. Two tumors which were histologically classified as common warts contained HPV types 27 and 28. All the 17 other HPV types belong to the group of epidermodysplasia-verruciformis-associated types. Conclusions: The majority of cutaneous lesions in CS contain HPV DNA. They may have a variety of histological patterns. Trichilemmomas are not clinically distinctive and can be difficult to identify in CS patients.

Copyright $\odot 2003$ S. Karger AG, Basel

\section{Introduction}

Cowden syndrome (CS, OMIM No. 158350) or multiple hamartoma syndrome is a cancer-associated genodermatosis inherited in an autosomal dominant pattern [1]. The gene for CS has been identified as PTEN (phosphatase and tensin homologue) at chromosome 10q22-23 [2]. The most common associated malignancies are carcinomas of the breast, thyroid and endometrium. The cutaneous changes are often the first sign so that an astute der- 
Table 1. Summary of patients

\begin{tabular}{|c|c|c|c|c|}
\hline Patient & DOB & Systemic involvement & Lesions & Code No. \\
\hline M.R. [27] & 3.9.1924 & $\begin{array}{l}\text { thyroid carcinoma, bilateral cystic bre- } \\
\text { ast disease, laryngeal papillomas }\end{array}$ & $4+2 \mathrm{~A}$ & $\begin{array}{l}22672 \\
22673 \\
22674 \\
22675 \\
12129 / 98 \\
12130 / 98\end{array}$ \\
\hline W.L. [28] & 13.4.1935 & $\begin{array}{l}\text { breast carcinoma, } \\
\text { malignant melanoma }\end{array}$ & $6+1 A$ & $\begin{array}{l}22676 \\
22677 \\
22678 \\
22679 \\
22680 \\
22681 \\
13292 / 99\end{array}$ \\
\hline B.G. [28] & 21.12 .1959 & cervical carcinoma, thyroid adenoma & $6+3 A$ & $\begin{array}{l}22682 \\
22683 \\
22684 \\
22685 \\
22686 \\
22687 \\
6652 / 99 \\
6653 / 99 \\
6654 / 99\end{array}$ \\
\hline G.K.P. [28] & 29.1 .1935 & bronchial carcinoma & $1 \mathrm{~A}$ & $11851 / 99$ \\
\hline B.R. [28] & 30.9 .1983 & macrocephaly, no tumors & $2 \mathrm{~A}$ & $\begin{array}{l}7640 / 99 \\
17589 / 99\end{array}$ \\
\hline F.G. [29] & 3.9.1941 & intestinal polyposis, thyroid adenoma & $3 \mathrm{~A}$ & $\begin{array}{l}2272 / 82 \\
1050 / 79 \\
3564 / 85\end{array}$ \\
\hline Not known & & $\begin{array}{l}\text { Hodgkin lymphoma, } \\
\text { intestinal polyposis }\end{array}$ & $1 \mathrm{~A}$ & 88956 \\
\hline Total & & & 29 & \\
\hline
\end{tabular}

DOB = Date of birth; A = archival material. G.K.P. is the father of B.G. and the grandfather of B.R.

matologist may make the initial diagnosis. The typical cutaneous lesions are wart-like; they have been variously described as facial papules and oral papules, as well as acral and palmoplantar keratoses. The facial papules may be trichilemmomas, benign hair follicle tumors; this finding is prominently featured in the diagnostic criteria. There has been a smoldering controversy over the possible role of human papillomavirus (HPV) in both solitary and CS-associated trichilemmomas. We studied a varied of skin lesions from patients with CS with both routine light microscopy and HPV DNA analysis.

HPV in Cowden Syndrome

\section{Patients and Methods}

We followed two approaches. We biopsied 16 lesions in 3 of our patients (M.R., W.L. and B.G.) with well-established CS. In each instance, the lesion was either facial or had verrucous features. The choice of lesions was somewhat limited by the willingness of the patient to endure multiple biopsies which were not of diagnostic or therapeutic utility. The material was fixed in standard formalin solution and embedded in paraffin. In addition, we obtained blocks of similarly prepared tissue both from these patients and 4 other individuals with CS. The clinical features of all these patients are summarized in table 1 . All had typical cutaneous changes and the only one without systemic tumors was a teenage boy (B.R.) with striking macrocephaly whose mother and grandfather (B.G. and G.K.P.) have clear CS.

Dermatology 2003;207:134-140 
Table 2. PCR results and histological diagnosis of all investigated specimens

\begin{tabular}{|c|c|c|c|c|c|}
\hline \multirow[t]{2}{*}{ Code No. } & \multirow{2}{*}{$\begin{array}{l}\text { Histological } \\
\text { diagnosis }\end{array}$} & \multicolumn{4}{|l|}{ Primer sets } \\
\hline & & $\begin{array}{l}\text { A } \\
\text { (genital } \\
\text { HPV types) }\end{array}$ & $\begin{array}{l}\text { B-1 } \\
\text { (HPV group B1, sub- } \\
\text { group A, EV-associated } \\
\text { HPV types 5, 8, 12, 14d, 19, } \\
\text { 20, 21, 24, 25, 36, 47 and } \\
\text { putative new types) }\end{array}$ & $\begin{array}{l}\text { B-2 } \\
\text { (HPV group B1, sub- } \\
\text { group B, EV-associated } \\
\text { HPV types } 9,15,17,22,23, \\
37,38,49,75,76,80 \text { and } \\
\text { putative new types) }\end{array}$ & $\begin{array}{l}\text { D } \\
\text { (cutaneous } \\
\text { HPV types } 3 \text {, } \\
10,27,28 \text { ) }\end{array}$ \\
\hline 22672 & VPSC & - & - & AF042006 ${ }^{1}$ & - \\
\hline 22673 & VPSC & - & - & 80 & - \\
\hline 22674 & VPSC & - & - & 37 & - \\
\hline 22675 & SK & - & - & 80 & - \\
\hline 22676 & $\mathrm{SH}$ & - & - & - & - \\
\hline 22677 & VPSC & - & - & 9 & - \\
\hline 22678 & VPSC & - & - & related to HPV 37 & - \\
\hline 22679 & VPSC (IFK) & - & - & related to HPV 37 & - \\
\hline 22680 & $\mathrm{SF}$ & - & - & - & - \\
\hline 22681 & $\mathrm{SF}$ & - & - & - & - \\
\hline 22682 & SK & - & - & - & - \\
\hline 22683 & VPSC & - & - & Z95965 (5) & - \\
\hline 22684 & $\mathrm{TL}$ & - & - & - & - \\
\hline 22685 & VPSC & - & - & AF042006 ${ }^{1}$ & - \\
\hline 22686 & VPSC & - & - & - & - \\
\hline 22687 & SK & - & - & - & - \\
\hline $6652 / 99$ & VPKC & - & - & - & 28 \\
\hline $6653 / 99$ & VPSC (IFK) & - & - & 9 & - \\
\hline $6654 / 99$ & VPSC & - & - & 9 & - \\
\hline $7640 / 99$ & VPKC & - & - & - & 27 \\
\hline $17589 / 99$ & VPKC & - & - & related to HPV 25 & - \\
\hline $11851 / 99$ & VPSC & - & - & AF042006 1 & - \\
\hline 88956 & VPSC (IFK) & - & - & 37 & - \\
\hline $12129 / 98$ & VPSC & - & - & 37 & - \\
\hline $12130 / 98$ & $\mathrm{TL}$ & - & - & 80 & - \\
\hline $2272 / 82$ & VPSC & - & - & - & - \\
\hline $1050 / 79$ & VPSC & - & - & - & - \\
\hline $3564 / 85$ & VPSC & - & - & Z95968 (5) & - \\
\hline $13292 / 99$ & $\mathrm{SF}$ & - & - & - & - \\
\hline
\end{tabular}

$\mathrm{TL}=$ Trichilemmoma; $\mathrm{VPKC}=$ viral papilloma with HPV-induced keratinocyte changes; VPSC = possible viral papilloma with structural changes; IFK = inverted follicular keratosis; $\mathrm{SK}=$ seborrheic keratosis; $\mathrm{SH}=$ sebaceous hyperplasia; SF = sclerotic fibroma. The difference between primer sets B-1 and B-2 is explained in Patients and Methods.

1 Genbank accession number; Summersgill K.F., Haugen T.H., Smith E.M., Turek L.P., direct submission, January 9, 1998, Pathology, VA Medical Center, Iowa City, Iowa, USA.

The lesions were studied by routine light microscopy employing hematoxylin and eosin-stained sections. In addition, the tissue was analyzed for the presence of HPV DNA. Five sections of each paraffin-embedded tissue sample were deparaffinized with xylene as described by Shibata [3]. DNA was then extracted using the QIAamp tissue kit (Qiagen, Germany). The DNA of each tissue sample was eluted in $100 \mu \mathrm{l}$ water, divided into $50-\mu \mathrm{l}$ aliquots and stored at $-20^{\circ} \mathrm{C}$ until use.

\section{Primer Sets and PCR Assays}

Detection and typing of mucosal, epidermodysplasia-verruciformis (EV)-associated and cutaneous HPV types were done by using nested PCR assays with different consensus primer sets (A, B-1, B-2 and $\mathrm{D}$ ) and direct sequencing of the amplicons. The used primer sets B-1 and B-2 enable the detection of subgroup A [4] (primer set B-1) and B [3] (primer set B-2) of HPV group B1 described by Chan et al. [5] (group B1, subgroup A: HPV, 5, 8, 12, 14d, 19, 20, 21, 24, 25, 36, 47; group B1, subgroup B: HPV 9, 15, 17, 22, 23, 37, 38, 49, 75, 76, 80 ). Using nested PCR assays, a high sensitivity for detection of the 


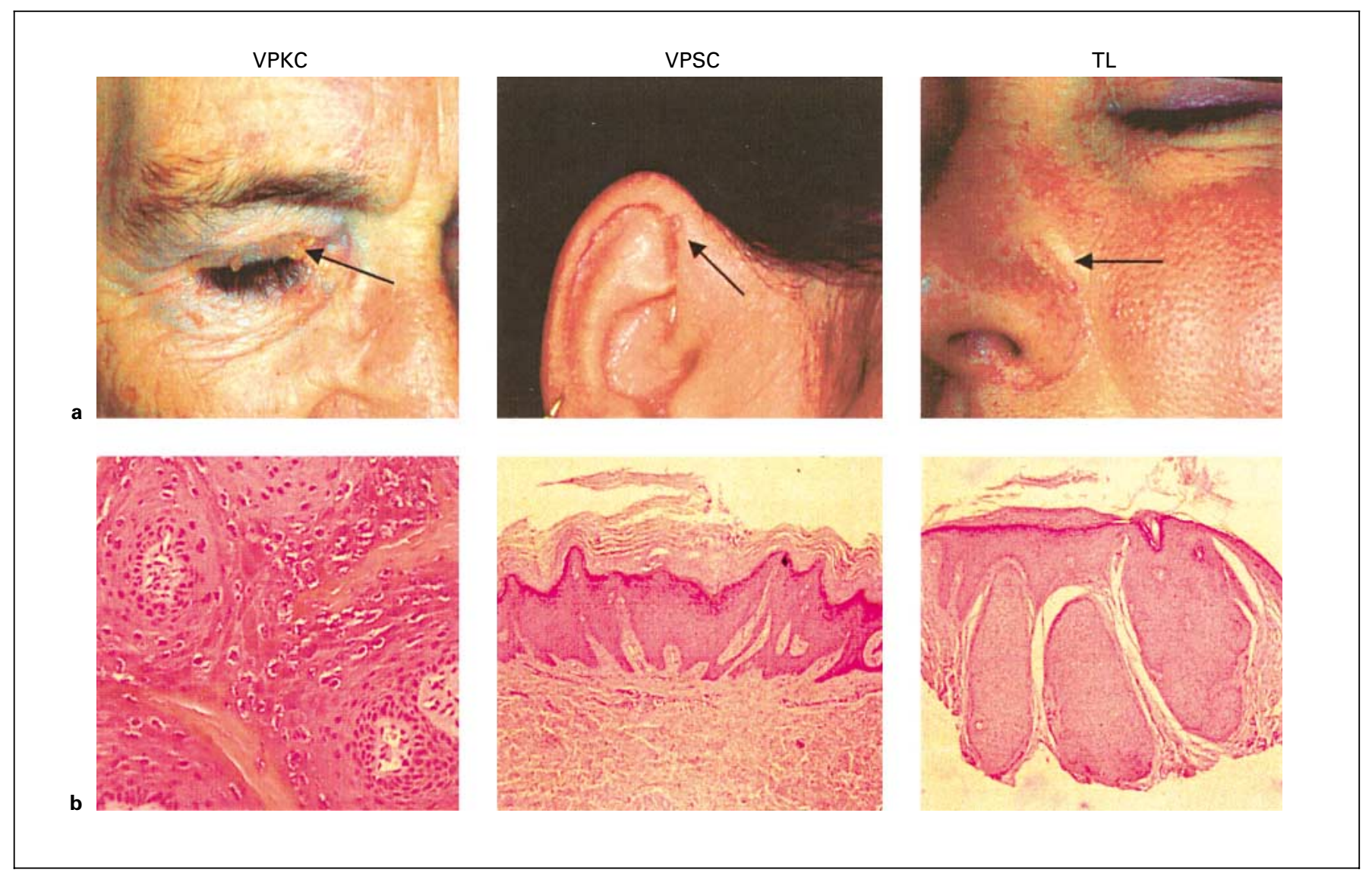

Fig. 1. Clinical (a) and histological (b) correlation of investigated tumors in CS: viral papilloma with keratinocyte changes (VPKC), viral papilloma with structural changes (VPSC) and trichilemmoma (TL).

different HPV types was achieved ranging between 2 and $10 \mathrm{HPV}$ genome equivalents.

The different primer pairs and the corresponding PCR assays have been described in detail [6]. Primer sets for detection of HPV group B2 (HPV 4, 48, 50, 60, 65) were not included in this study because these types, especially HPV 60, are more associated with plantar epidermoid cysts [7, 8].

Positive controls (previously HPV-5 and -17-positive tested tissue samples) and negative controls (water or HPV-negative tissue) were processed the same way as the samples throughout the first-step and second-step PCR. We used kidney and liver tissue specimens from rats as well as previously HPV-negative tested human skin specimens as negative controls. The PCR products ( $10 \mu \mathrm{l}$ of each) were analyzed on $2 \%$ agarose gels stained with $1 \mu \mathrm{g} / \mathrm{ml}$ of ethidium.

\section{Sequencing}

For determination of the HPV types, the amplification products of the expected size were purified using the Qiagen PCR purification kit or the QIAquick gel extraction kit (Qiagen) and subsequently sequenced by cycle sequencing with the Prism ${ }^{\mathrm{TM}}$ Ready Reaction Dye Deoxy ${ }^{\mathrm{TM}}$ Terminator Cycle Sequencing Kit (Applied Biosystems, Germany) using the same primers which were used for the
PCR assay. The sequences were then compared to the EMBL database (virus part) using the FASTA program (EMBL).

\section{Results}

Table 2 shows the histological diagnoses and the results of the HPV DNA studies in the 29 lesions. The two skin tumors classically associated with CS are trichilemmomas and sclerotic fibromas. We found only 2 trichilemmomas and 3 sclerotic fibromas. In addition, we identified 1 sebaceous hyperplasia.

The other 23 tumors all had histological features of HPV-induced tumors in various stages of development. We distinguished between a viral papilloma with HPVinduced keratinocyte changes and a possible viral papilloma with structural changes (fig. 1). The presence or absence of koilocytes was used to determine which tumors were viral papillomas with keratinocyte changes; 2 pa- 
tients had a total of 3 classical verrucae vulgares. The group with structural changes was more heterogeneous. These tumors showed acanthosis, focal hypergranulosis, parakeratosis and occasional hemorrhage in the stratum corneum. There was no evidence of cell atypia. We further classified these lesions as plane warts (4), filiform warts (4) and old warts (2). We defined an old wart as a typical verruca vulgaris without koilocytes. A similar lesion with horn pseudocysts was designated as seborrheic keratosis; 3 were identified. In addition we found 3 inverted follicular keratoses which we included as old warts but identified separately because they clearly involved the hair follicle.

All 29 samples were analyzed for the presence of HPV DNA, which was found in 19 of 29 lesions. Using the different primer sets, 5 distinct HPV types $(9,37,80,27,28)$ and 3 putative new types (DL253 and DL285, accession No. Z95965, Z95968 [9], and isolate IA18 [Summersgill et al., unpubl. results], accession No. AF042006) were detected and typed. Furthermore, in 3 cases we found sequences, which were closely related but not identical to the well-characterized types 25 and 37 . They may represent new types or highly mutated variants of the established types.

The correlation of the histological appearance of the lesions with the HPV type showed that HPV DNA was only detected in skin tumors with architectural or cytological criteria of a HPV histogenesis (trichilemmoma, viral papilloma with keratinocyte changes or structural changes, inverted follicular keratosis, seborrheic keratosis). Tumors without any histological sign of HPV induction (sebaceous hyperplasia and sclerotic fibroma) were negative in the HPV PCR analysis as were the negative controls.

Types 27 and 28 were the only cutaneous-type HPV to be identified, and they were found in 2 lesions, which were histologically common warts with virally transformed keratinocytes. All other HPV types belong to group B1, EV-associated types (table 2).

\section{Discussion}

The exact nature of the cutaneous lesions in CS has long been controversial. Brownstein et al. [10] and Starink et al. [11] were the first to identify multiple trichilemmomas as a marker for CS. Brownstein et al. [10] found that about 54\% of facial lesions removed from 19 patients were trichilemmomas, while Starink et al. [11] studied 29 facial biopsies in 7 patients, finding $66 \%$ trichilemmomas. Gradually multiple trichilemmomas became accepted as a major diagnostic criterion for CS. In the latest guidelines, the presence of 6 facial papules, 3 of which are trichilemmomas, is considered diagnostic [12].

There are two basic problems with this approach. First, patients with CS do not have 4 clinically distinct types of lesions - facial papules, acral fibromas, palmoplantar keratoses and oral papules. Instead, there is a marked degree of clinical overlap, as our sampling shows. Papules may be smooth or warty, regardless of whether they are acral, facial or mucosal. Lesions may also be seen in flexural areas, as well as scattered over the body. In general, the facial lesions are more likely to resemble common or filiform warts, while the acral lesions are more similar to plane warts. Ackerman et al. [13] argued convincingly that clinically the lesions are most suggestive of warts in varying stages of evolution, with slightly different appearances based on location.

Second, histology does not resolve the issue. Some lesions are papillomatous with granular layer changes, suggesting that they are warts. Most acral lesions are not papillomatous but may still show granular layer changes compatible with a plane wart. Even the lesions that are accepted as trichilemmomas, showing a clear-cell tumor involving a hair follicle, often have some verrucous features. Ackerman et al. [13-15] feel that all trichilemmomas are HPV infections involving the hair follicle. We have previously identified HPV DNA in 11 of 11 solitary trichilemmomas in patients without CS [16]. In the only other study, using a less sensitive detection system, Leonardi et al. [17] failed to find HPV DNA in solitary trichilemmomas.

Much progress has been made in the detection of HPV both from lesions and in normal skin. As demonstrated previously by several investigators, the use of different broad-spectrum primer sets enables the identification of most of the more than 90 known HPV types, as well as putative novel HPV types [9, 18-20]. In spite of the improved methodology for the detection of cutaneous and EV-associated papillomaviruses, little is known about the possible role of these HPV types in carcinogenesis. Genital HPV types, especially HPV 16 and 18, have been extensively investigated in view of viral gene expression, host cell interaction and their influence during the cell cycle; no comparable studies are available for the cutaneous and $\mathrm{EV}$-associated types.

We offer the following two speculations about the relationship of CS and HPV.

(1) Patients with CS may well have a single cutaneous lesion with varying clinical and histological patterns depending on location and age.

As Ackerman et al. [21] have pointed out, when experienced clinicians are unable to distinguish between 2 histo- $\overline{138} \quad \overline{\text { Dermatology 2003;207:134-140 }}$
Schaller/Rohwedder/Burgdorf/Itin/ Lautenschlager 
logically distinct lesions in the same patient, it is likely that these lesions represent different stages in the evolution of a single lesion. Two other examples of this phenomenon are the keratoacanthomas and sebaceous tumors in Muir-Torre syndrome and the fibrofolliculomas and trichodiscomas in Birt-Hogg-Dubé syndrome [21]. In both instances, it is impossible to accurately separate the lesions clinically, and it has been accepted that they represent the same tumor.

From our patients with CS whom we biopsied specifically for this study (patients W.L., M.R., B.G.), we learned that it can be extremely difficult to identify trichilemmomas. Two experienced clinicians with an interest in genodermatoses (W.B., P.I.) selected the lesions feeling they fit the published criteria for trichilemmomas. Of the 16 biopsies taken in this fashion, only 2 revealed trichilemmomas, a batting average of 0.125 . We conclude that trichilemmomas are often not clinically distinctive and that it is an error to assume that all facial lesions of CS are trichilemmomas. In some of the studies in the literature [11], the illustrations suggest that lesions which we designated as viral papillomas with structural changes have been included as trichilemmomas.

(2) HPV DNA is found in the cutaneous lesions of CS.

We identified HPV DNA in 19 of 29 lesions in this study. We have also found similar HPV DNA sequences in solitary trichilemmomas [16]. It is surely conceivable that HPV could cause both solitary and CS-related trichilemmomas. Since HPV is common in hair follicles and found often on facial skin, it is difficult to argue that its presence in many of the lesions of CS proves an etiological connection. In one study, EV-associated HPV DNA was found in plucked eyebrow hair in about $50 \%$ of adults
[22]. It is well accepted that the hair follicle is both one of the permanent sources of HPV DNA and the site of origin of trichilemmomas. The likelihood of finding HPV is greater in sun-exposed skin. Biopsies from W.L. (2267622681) were from non-sun-exposed sites and some still contained HPV DNA. As known for high-risk HPV types (e.g. 16, 18) the oncoproteins E6 and E7 as well as the viral regulatory protein E2 could influence and override the different checkpoints of the cell cycle using varied mechanisms resulting in genomic instability [23-26]. Since nearly all studies about virus-induced carcinogenesis and the function of the viral regulatory proteins were done with high-risk HPV types, especially HPV 16, very little is known about the importance of the cutaneous and EVassociated HPV types and also about the function of the regulatory proteins of these viruses. Further studies of the transcription and protein expression are necesssary to clarify the role of HPV in the induction of trichilemmomas and other lesions associated with CS.

In sum, the number of questions raised by our study clearly exceeds the answers we have provided. Patients with CS develop warty lesions, which are difficult to diagnose clinically. In many of these lesions, EV-associated HPV types can be found, and a classification is only possible by histological and molecular-biological investigation.

\section{Acknowledgment}

We thank Bernhard Zelger, MD (Department of Dermatology, University of Innsbruck, Austria), and Javier Gutierrez de la Pena, MD (Palma de Mallorca, Spain), for the biopsy material and clinical data on 2 patients (F.G. and N.K.).

\section{References}

1 Eng C, Parsons R: Cowden syndrome; in Scriver CR, et al. (eds): The Metabolic and Molecular Bases of Inherited Disease, ed 8. New York, McGraw-Hill, 2001, pp 979-988.

2 Nelen MR, Padberg GW, Peeters EA, Lin AY, van den Helm B, Frants RR, Coulon V, Goldstein AM, van Reen MM, Easton DF, Eeles RA, Hodgsen S, Mulvihill JJ, Murday VA, Tucker MA, Mariman EC, Starink TM, Ponder BA, Ropers HH, Kremer H, Longy M, Eng C: Localization of the gene for Cowden disease to chromosome 10q22-23. Nat Genet 1996;13: 114-116.
3 Shibata DK: The polymerase chain reaction and the molecular genetic analysis of tissue biopsies; in Herrington CS, McGee JO'D (eds): Diagnostic Molecular Pathology: A Practical Approach. Oxford, IRL Press, 1992, vol II, pp 85-111.

4 Berkhout RJ, Bouwes Bavinck JN, ter Schegget $\mathrm{J}$ : Persistence of human papillomavirus DNA in benign and (pre)malignant skin lesions from renal transplant recipients. J Clin Microbiol 2000;38:2087-2096.

5 Chan SY, Delius H, Halpern AL, Bernard HU: Analysis of genomic sequences of 95 papillomavirus types: Uniting typing, phylogeny, and taxonomy. J Virol 1995; 69:3074-3083.
6 Rohwedder A, Philips B, Malfetano J, Kredentser D, Carlson JA: Vulvar malignant melanoma associated with HPV DNA. Am J Dermatopathol 2002;24:230-240.

7 Kawase M, Honda M, Niimura M: Detection of human papillomavirus type 60 in plantar cysts and verruca plantaris by the in situ hybridization method using digoxigenin labeled probes. J Dermatol 1994;21:709-715.

8 Elston DM, Parker LU, Tuthill RJ: Epidermoid cyst of the scalp containing human papillomavirus. J Cutan Pathol 1993;20:184-186.

9 De Villiers EM, Lavergne D, McLaren K, Benton EC: Prevailing papillomavirus types in non-melanoma carcinomas of the skin in renal allograft recipients. Int J Cancer 1997;73:356361. 
10 Brownstein MH, Mehregan AH, Bikowski JB, Lupulescu A, Patterson JC: The dermatopathology of Cowden's syndrome. Br J Dermatol 1979; 100:667-673.

11 Starink TM, Meijer CJ, Brownstein MH: The pathology of Cowden's disease: New findings. J Cutan Pathol 1985;12:83-93.

12 Eng C: Will the real Cowden syndrome please stand up: Revised diagnostic criteria. J Med Genet 2000;37:828-830.

13 Ackerman AB, de Viragh PA, Chongchitnant $\mathrm{N}$ : Tricholemmoma; in Spahr JF Jr, DiRienzi DA (eds): Neoplasms with Follicular Differentiation. Philadelphia, Lea \& Febiger, 1993, pp 333-356.

14 Ackerman AB: Trichilemmoma. Arch Dermatol 1978; 114:286.

15 Ackerman AB, Wade TR: Tricholemmoma Am J Dermatopathol 1980;2:207-224.

16 Rohwedder A, Keminer O, Hendricks C, Schaller J: Detection of HPV-DNA in trichilemmoma by polymerase chain reaction. $\mathrm{J} \mathrm{Med}$ Virol 1997;51:119-125.

17 Leonardi CL, Zhu WY, Kinsey WH, Penneys NS: Trichilemmomas are not associated with human papillomavirus DNA. J Cutan Pathol 1991;18:193-197.
18 Boxman IL, Berkhout RJ, Mulder LHC, Bouwes Bavinck JN, ter Scheggert J: Detection of human papillomavirus DNA in plucked hairs from renal transplant recipients and healthy volunteers. J Invest Dermatol 1997; 108:712-715.

19 Astori G, Lavergne D, Benton C, Hockmayr B, Egawa K, Garbe C, et al: Human papillomaviruses are commonly found in normal skin of immunocompetent hosts. J Invest Dermatol 1998;110:752-755.

20 Harwood CA, Spink PJ, Surentheran T, Leigh IM, De Villiers EM, McGregor JM, et al: Degenerate and nested PCR: A highly sensitive and specific method for detection of human papillomavirus infection in cutaneous warts. $\mathbf{J}$ Clin Microbiol 1999;37:3545-3555.

21 Ackerman AB, de Viragh PA, Chongchitnant $\mathrm{N}$ : Fibrofolliculoma and trichodiscoma; in Spahr JF Jr, DiRienzi DA (eds): Neoplasms with Follicular Differentiation. Philadelphia, Lea \& Febiger, 1993, pp 245-279.

22 Boxman ILA, Russell A, Mulder LHC, Bouwes Bavinck JN, ter Scheggert J, Green A: Association between epidermodysplasia verruciformis-associated human papillomavirus DNA in plucked eyebrow hair and solar keratoses. J Invest Dermatol 2001;117:1108-1112.

23 zur Hausen H: Papillomaviruses causing cancer: Evasion from host-cell control in early events in carcinogenesis. J Natl Cancer Inst 2000;92:690-698.
24 Gualberto A, Aldape K, Kozakiewicz K, Tlsty TD: An oncogenic form of p53 confers a dominant, gain-of-function phenotype that disrupts spindle checkpoint control. Proc Natl Acad Sci USA 1998;95:5166-5171.

25 Hixon ML, Flores A, Wagner M, Gualberto A: Gain of function properties of mutant p53 proteins at the mitotic spindle cell cycle checkpoint. Histol Histopathol 2000;15:551-556.

26 Duensing S, Lee LY, Duensing A, Basile J, Piboonniyom S, Gonzalez S, et al: The human papillomavirus type 16 E6 and E7 oncoproteins cooperate to induce mitotic defects and genomic instability by uncoupling centrosome duplication from the cell division cycle. Proc Natl Acad Sci USA 2000;97:10002-10007.

27 Hildenbrand C, Burgdorf WHC, Lautenschlager S: Cowden syndrome - Diagnostic skin signs. Dermatology 2001;202:362-366.

28 Fistarol SK, Anliker MC, Itin PH: Cowden disease or multiple hamartoma syndrome - Cutaneous clue to internal malignancy. Eur J Dermatol 2002;12:411-421.

29 Fritsch P, Pechlaner R, Czarnecki N, Hintner H: Das Multiple-Hamartome-Syndrom (Cowden-Syndrom). Hautarzt 1981;32:285-291. 